\title{
BALDO I ANTE BIBICA, OTAC I SIN - DVA DUBROVAČKA LIJEČNIKA
}

\section{BALDO AND ANTE BIBICA, FATHER AND SON - TWO PHYSICIANS FROM DUBROVNIK}

\author{
Ivica Vučak*, Ana Bakija-Konsuo**
}

\begin{abstract}
SAŽETAK
Zdravstvo i liječnici koji su djelovali u Dubrovniku u posljedna dva stoljeća, nakon što je Napoleonova armija srušila Dubrovačku Republiku, manje su do sada privlačili pozornost medikohistoričara. U ovom su članku na temelju podataka iz onodobnih časopisa i novina te privatnih arhiva članova obitelji rekonstruirani životi i djelovanje dvojice dubrovačkih liječnika, oca i sina, Balda i Ante Bibice koji su živjeli potkraj ig. i u prvoj polovici 20. stoljeća. Baldo Bibica medicinu je završio u Beču i čitavog je života bio općinski liječnik, najprije u mjestima u okolici Dubrovnika, a od 1903. u Gružu. Ante Bibica studirao je medicinu u Gracu i Zagrebu i bio prvi Dubrovčanin koji je diplomu liječnika dobio na Medicinskom fakultetu zagrebačkog Sveučilišta. Specijalizirao je dermatovenerologiju u Beču i radio kao specijalist u Dubrovniku. Obojica su bili članovi liječničkih udruženja (na lokalnoj i na nacionalnoj razini), a bili su utjecajni i u društvenom životu grada.
\end{abstract}

Ključne riječi: medicina, povijest medicine, Dubrovnik, Dalmacija, Hrvatska

\section{UvoD}

O povijesti medicine i o pojedinim liječnicima koji su djelovali u razdoblju Dubrovačke Republike objavljeno je više radova, no o razdoblju

\footnotetext{
Hrvatsko društvo za povijest medicine Hrvatskog liječničkog zbora, Zagreb, Hrvatska.

** Poliklinika za kožne i spolne bolesti „Cutis“, Dubrovnik, Hrvatska.

Adresa za dopisivanje: Ivica Vučak, Hrvatsko društvo za povijest medicine Hrvatskog liječničkog Zbora, Šubićeva 9, 10000 Zagreb. ORCID ID: https://orcid.org/0000-0003. 0125-9607.E-pošta: ivica.vucak@gmail.com.
} 
nakon njezina pada dolaskom Napoleonove vojske, odnosno od početka 19. stoljeća do danas pisano je manje. Brojni su liječnici svojim stručnim ili znanstvenim radom ostavili trag u medicinskoj prošlosti Dubrovnika u posljednja dva stoljeća. Dr. Baldo i dr. Ante Bibica, otac i sin, podrijetlom s poluotoka Pelješca, djelovali su potkraj I9. i u prvoj polovici 20. stoljeća. Stariji se spominje u literaturi o nastanku Stranke prava u Dalmaciji, a o mlađemu, prvom Dubrovčaninu promaknutom na Medicinskom fakultetu (MEF) zagrebačkog Sveučilišta, pisano je u kontekstu istraživanja razvitka dermatovenerologije u Dubrovniku i u povodu stote obljetnice MEF-a u Zagrebu. ${ }^{1-7}$ Njihove životne putove, stručni i društveni rad pokušali smo rasvijetliti pretraživanjem tiskovina i stručnih (lokalnih i nacionalnih) glasila toga razdoblja. Koristili smo se i podacima dobivenim od potomaka njihove obitelji.

\section{Baldo Bibica}

(Zagruda/Kuna, 22. travnja I866. - Dubrovnik, 8. veljačE i924.)

Baldo (Balthasar) Bibica rođen je 22. travnja i866. u obitelji Marije rođene Hilić i Antuna Bibice, posjednika u malome mjestu Zagruda, župa Kuna, na poluotoku Pelješcu. Nakon završenih osam razreda u Velikoj državnoj gimnaziji u Dubrovniku maturirao je s ocjenom „zrio“ 27. srpnja I886. godine. ${ }^{8}$ Tada još nije postojao studij medicine u Hrvatskoj pa su mladi Hrvati odlazili na ugledna sveučilišta u Austro-Ugarskoj Monarhiji ili izvan nje. Bibica je odabrao Beč. I nakon smrti oca Antuna I89ı., nastavio je studij u Beču, a kao skrbnik mu je bio upisan Ivan Milić Kovač, zemljoposjednik. Tijekom studiranja u Beču sudjelovao je u radu udruženja hrvatskih studenata pod nazivom Hrvatsko akademsko društvo Zvonimir (HAD Zvonimir). Prema izviješćima o glavnim skupštinama Zvonimira biran je za odbornikovog zamjenika (I886.),

1 Hajdarhodžić, Hamdija, Arneri, Rafo, Maroević Hrvoje, Nemec Marija (1963) Korespodencija Frana Supila iz perioda 1891. - 1914. Arh vjesn 6, 40. Dostupno na: https://library.hungaricana.hu/hu/view/CroatianStateArchives_AV_III_06_1963/?pg = 43\&layout = s\&query = bibica\%20baldo (pristupljeno 21. srpnja 2019.).

2 Diklić, Marjan (1998) Pravaštvo u Dalmaciji do kraja prvoga svjetskoga rata, Matica hrvatska Zadar i Zavod za povijesne znanosti Hrvatske akademije znanosti i umjetnosti u Zadru, Zadar, 198. Isto, 263.

4 Isto, 279.

5 Bakija-Konsuo, Ana (2011) Obilježavanje 40 godina rada Službe za kožne i spolne bolesti u Dubrovniku, Dubrovački horizonti, 48, 40-50.

6 Bakija-Konsuo, Ana and Marlais, Matko (2012) A brief history of Dermatovenereology in Dubrovnik, Acta Dermatovenerol Croat 20, 141-7.

7 Bakija-Konsuo, Ana i Vučak, Ivica (2017) Dr. Ante Bibica (1897-1973) - prvi Dubrovčanin s diplomom zagrebačkog Medicinskog fakulteta, Liječ nov br. 158, travanj 2017, 92-3.

8 Anonim (1866). Esami di maturità. Narod br. 60, 3. 8. 1866, 3. 
potom za drugoga tajnika (I887.) i na kraju za potpredsjednika (I889.).9-11 Bio je član društva Bratovščina hrvatskih ljudi u Istri kojem je u razdoblju između 4. rujna i 8 . listopada 1887 . darovao jednu forintu. ${ }^{12} \mathrm{Od} 3 \mathrm{I}$. svibnja do 15 . listopada I889. medicinar Bibica je na Pelješcu prikupljao priloge za Hrvatsko pripomoćno društvo u Beču koje je najsiromašnijim hrvatskim studentima osiguravalo smještaj i prehranu. ${ }^{13}$ Sva tri stroga ispita (I6. srpnja I89I.; I5. srpnja I892. i I5. ožujka I893.) položio je s ocjenom “dostatno”. Njegova promocija u Beču I8. ožujka I893. obznanjena je u glasilu Crvena Hrvatska koji je u Dubrovniku 7. veljače I89I. pokrenuo i uređivao tada dvadesetogodišnji Frano Supilo (I870. - I917.). ${ }^{14}$ Promociju na čast doktora liječništva Balde Bibice, „sina kršne Dalmacije“, spomenula je i Naša Sloga koju je uređivao i na hrvatskom jeziku u Trstu tiskao Matko Mandić (I849. - I9I5.). ${ }^{15}$,

\section{NAKON PROMOCIJE}

Prema Zakonu o uređenju zdravstvene službe u općinama, koji je Dalmatinski sabor u Zadru donio 27. veljače i874., općine s 6000 i više stanovnika bile su dužne imati općinskog, javnog liječnika (ako općina ima manje stanovnika, onda u zajednici sa susjednom općinom). Općinsko je vijeće izabranom liječniku određivalo plaću. Liječnici su radili i u privatnoj praksi, a svoje privatne ordinacije imali su i svi oni koji su radili u javnoj službi. Djelovali su kao liječnici sveukupne medicine. U specijalističkim su se znanjima i vještinama osposobljavali na tečajevima ili posjetima većim medicinskim centrima i tako se usavršavali u nekoj grani medicine. Liječnika specijalista, u modernom smislu, u Dalmaciji nije bilo. Na prijedlog dr. Nikole baruna Lalića (I872. - I9I7.) provedena je I889./I89o. prva podjela rada među liječnicima, premda neslužbena, u šibenskoj bolnici. Kao primarni liječnik, on je preuzeo kirurgiju, a pomoćnog liječnika dr. Božu Peričića (I865. - I947.), Bibičina kolegu iz bečkih studentskih dana i iz HAD Zvonimira, zadužio za internističku problematiku, zarazne bolesti te kožne i spolne bolesti. ${ }^{16}$

Anonim (1886).HAD “Zvonimir“. Glas Hercegovca br. 46, 13. 11. 1886, 4.

Anonim (1887). Hrv. akad. Društvo „Zvonimir“ u Beču. Narodni List br. 87, 5. 11. 1887, 3.

Anonim (1889). Godišnja skupština HAD “Zvonimir”-a. Narodni List br. 88, 6. 11. 1889, 3.

Anonim (1887). Članovi "Bratovščine hrvatskih ljudi u Istri“. Naša Sloga br. 44, 3. $11.1887,3$.

13 Anonim (1889). Iz Hrvatskog pripomoćnog društva u Beču. Obzor br. 255, 5. 11. 1889, 3.

Anonim (1889). Promocija. Crvena Hrvatska br. 13, 1. 4. 1894, 3.

Anonim (1893). Pet naših doktura u dva dana. Naša Sloga br. 12, 23. 3. 1893, 2.

16 Peričić, Božo (1933) Kao mlad ljekar u šibenskoj bolnici, u: Machiedo, Jerko, Lalić, Jozo, Škarica, Miloš (ur.) Spomen-knjiga o pedesetgodišnjici banovinske bolnice u Šibeniku, 18831933, Šibenik, 53-7. 
U drugoj polovici listopada I893. "Dr. Baldu Bibici iz Zagrude kunovske pripoznato je pravo slobodna vršenja liečničkoga zvanja". ${ }^{17} \mathrm{U}$ početku je Baldo Bibica obavljao posao općinskog liječnika u Vrgorcu. ${ }^{18}$ Zatim se vratio u rodni kraj. Došao je na mjesto općinskog liječnika u Orebiću na kojem je do 2. siječnja 1894. bio dr. Serafin Šantić (I866. - 1903.). ${ }^{19}$ Nakon rada u Orebiću Bibica je 17. srpnja 1894. preselio u Kunu. ${ }^{20} \mathrm{Na}$ piru "odličnog Hrvata Mata Orhanovića na Oskorušnu" prikupio je $2 \mathrm{I}$ forintu i preko uredništva Crvene Hrvatske poslao u kolovozu i894. upravi Družbe sv. Ćirila i Metoda u Istri. ${ }^{21}$ I u prigodi nenadane smrti svoga prijatelja i kolege Stonjanina dr. Rudolfa Milovčića (I868. - I899.), u studentskim danima predsjednika Zvonimira, darovao je I899. dr. Bibica deset kruna Družbi sv. Ćirila i Metoda u Istri. ${ }^{22,23}$

Dr. Bibica je najprije bio član Narodne hrvatske stranke u Dalmaciji, a potom je "iz nezadovoljstva politikom vlastite stranke" prišao krugu pravaša. ${ }^{1,2}$ Sljedbenici Ante Starčevića u Dalmaciji sudjelovali su u prikupljanju novca za izgradnju Starčevićeva doma u Zagrebu. Pridružili su se i akciji koju je I888. pokrenuo biskup Josip Juraj Strossmayer darovanjem 20.000 forinti za Zakladu za osnutak Medicinskog fakulteta na Sveučilištu u Zagrebu. ${ }^{24}$ Uredništvo Crvene Hrvatske je 22. srpnja 1893. u Zagreb poslalo 47 kruna za MEF u Zagrebu i i 84,7 kruna za Starčevićev dom, prikupljenih u Dubrovniku, a prvi darovatelji bili su Supilo i ravnatelj dubrovačke bolnice dr. Roko Mišetić (I845. - 1908.). ${ }^{25-28}$ Dr. Bibica je bio jedan od trojice predstavnika pravaša dubrovačkog okružja na sastanku u Zadru 22. i 23. kolovoza I894., na kojem je stvorena jedinstvena Stranka prava za Dalmaciju i imenovan dio članova Okružnog odbora za južnu Dalmaciju (bivše dubrovačko i kotorsko okružje). ${ }^{1.4}$ Nakon fuzije dalmatinske Stranke prava sa starim narodnjacima u proljeće ig05., bio je dr. Bibica pristaša novostvorene Hrvatske stranke, no

\footnotetext{
Anonim (1893). Dr. Baldo Bibica. Narodni list br. 84, 21.10. 1893, 3.

Anonim (1893). Transfer. Das Österreichische Sanitätswessen br. 44, 2. 11. 1893, 520.

Anonim (1894). Premještaj. Narodni list br. 5, 17. 1. 1894, 3.

Anonim (1894). Dr. Baldo Bibica. Crvena Hrvatska br. 30, 28. 7. 1894, 4.

Anonim (1894). "Družtvo sv. Ćirila i Metoda u Istri". Crvena Hrvatska br. 32, 11. 8. 1894, 3.

Anonim (1899). Iznenadna smrt. Osvit br. 17, 25. 2. 1899, 5.

Anonim (1899). "Družba sv. Ćirila i Metoda u Istri”. Narodni list br. 19, 8 .3. 1899, 3.

Vučak, Ivica (2019). Zaklada za osnutak Medicinskog fakulteta u Zagrebu, Liječ nov br. 182, str. 71-3.

Anonim (1893). Iz Uredništva. Crvena Hrvatska br. 29, 22. 7. 1893, 4.

Anonim (1893). Prve krune. Crvena Hrvatska br. 23, 10. 6. 1893, 3.

Anonim (1893). Prve krune. Crvena Hrvatska br. 24, 17. 6. 1893, 3.

Marinović, Ivo (2006). Liječnici dubrovačke bolnice; od 1840. do 1940. Zagreb, Medicinska naklada, 44-59.
} 
njegovom stranačkom aktivizmu u kasnijim godinama nema traga, za razliku od njegovih kolega dr. Mišetića i dr. Nike Marinkovića (I86I. - I9I6.).1,29

U ljeto i895. pristupio je dr. Bibica, općinski liječnik u Kuni, Hrvatskom starinarskom društvu u Kninu kao redoviti član (godišnji prinos tri forinte, uz četverogodišnju obvezu članstva) i primao društveno glasilo Starohrvatsku prosvjetu (izlazilo četvrtgodišnje od početka I895.). ${ }^{30}$ Prema "Imeniku redovitih članova Hrvatskog starinarskog društva I896. godine” bio je kratko vrijeme općinski liječnik u Imotskome. ${ }^{31}$ Potom je postao općinski liječnik u Veloj Luci na otoku Korčuli. U ljeto I899. pristupio je Zboru liječnika kraljevina Hrvatske i Slavonije u Zagrebu. ${ }^{32}$ Uplatio je i dvije forinte za troškove organizacije obilježavanja 25. obljetnice osnutka Zbora (I874. - I899.). ${ }^{33} \mathrm{Od}$ dalmatinskih liječnika na svečanom skupu u Zagrebu aktivno je sudjelovao dr. Peričić, tada liječnik u zadarskoj bolnici, i u auli Sveučilišta održao predavanje o najučestalijim bolestima s kojima se susreću liječnici u Dalmaciji. ${ }^{34}$ Bibica je ostao član Zbora liječnika do kraja života. Godine 1906. njegovo se ime našlo među I77 članova koji su kasnili s plaćenjem članarine zaključno s tom godinom. ${ }^{35}$ Dugovao je ro kruna, iznos jednogodišnje članarine.

Ujesen I903. preselio je s obitelji u Dubrovnik gdje je sve do smrti radio kao općinski liječnik u ordinaciji u Gružu, dijelu Dubrovnika izvan gradskih zidina, nasuprot poluotoka Lapad. U braku s Đinom rođ. Cviličević imao je sinove Vinka, Antu i Ivu te kćer Nevenku (slika r.).

Prema zakonskoj obvezi učlanjen je u Liječničku komoru koja je u Kraljevini Dalmaciji zaživjela II. srpnja I903., nakon više od desetljeća napora oko njezina osnutka, no njegovo ime nije među liječnicima posebice angažiranima u tome pothvatu. ${ }^{36}$ Bio je član Slobodnog udruženja liječnika Dalmacije (SOLD) utemeljenoga 20. kolovoza 1907. u Splitu zbog nezadovoljstva dalmatinskih liječnika rezultatima rada Liječničke komore. Na glavnoj skupštini i6. travnja igı 4. u Splitu (nazočilo joj je I3 od 7i člana) izabran je

29 Vučak, I. (2004) Nikola Marinković - prvi predsjednik Liječničke komore u Dalmaciji - uz stotu obljetnicu njezina osnutka. Liječ nov br. 32, 53-5.

30 Anonim (1895). Godišnja skupština. Starohrvatska prosvjeta 1:260.

31 Anonim (1896). Imenik redovitih članova Hrvatskog starinarskog društva 1896. godine. Starohrvatska prosvjeta 2:268.

32 Anonim (1899). Novi članovi. Liječ vjesn 21:312.

33 Anonim (1899). Proslava 25. godišnjice obstanka sbora liečnika kraljevina Hrvatske i Slavonije u Zagrebu. Prinos od 2 for. uplatili su do 5. prosinca 1899. Liječ vjesn 21:451.

34 Peričić, B. (1899). O razprostranjenju nekih bolesti po Dalmaciji. Liječ vjesn 21:428.

35 Anonim (1906). Iskaz p.n. gg. članova koji svoj prinos sboru duguju uključivo godinu 1906. Liječ vjesn 28 (11-prilog):1-4.

36 Vučak, Ivica (2015). Liječnička komora u Dalmaciji od 1903. do 1946. u Poljak, Željko i Vučak, Ivica (ur.) Hrvatska liječnička komora 2005. - 2015. HLK Zagreb, 34 -54. 


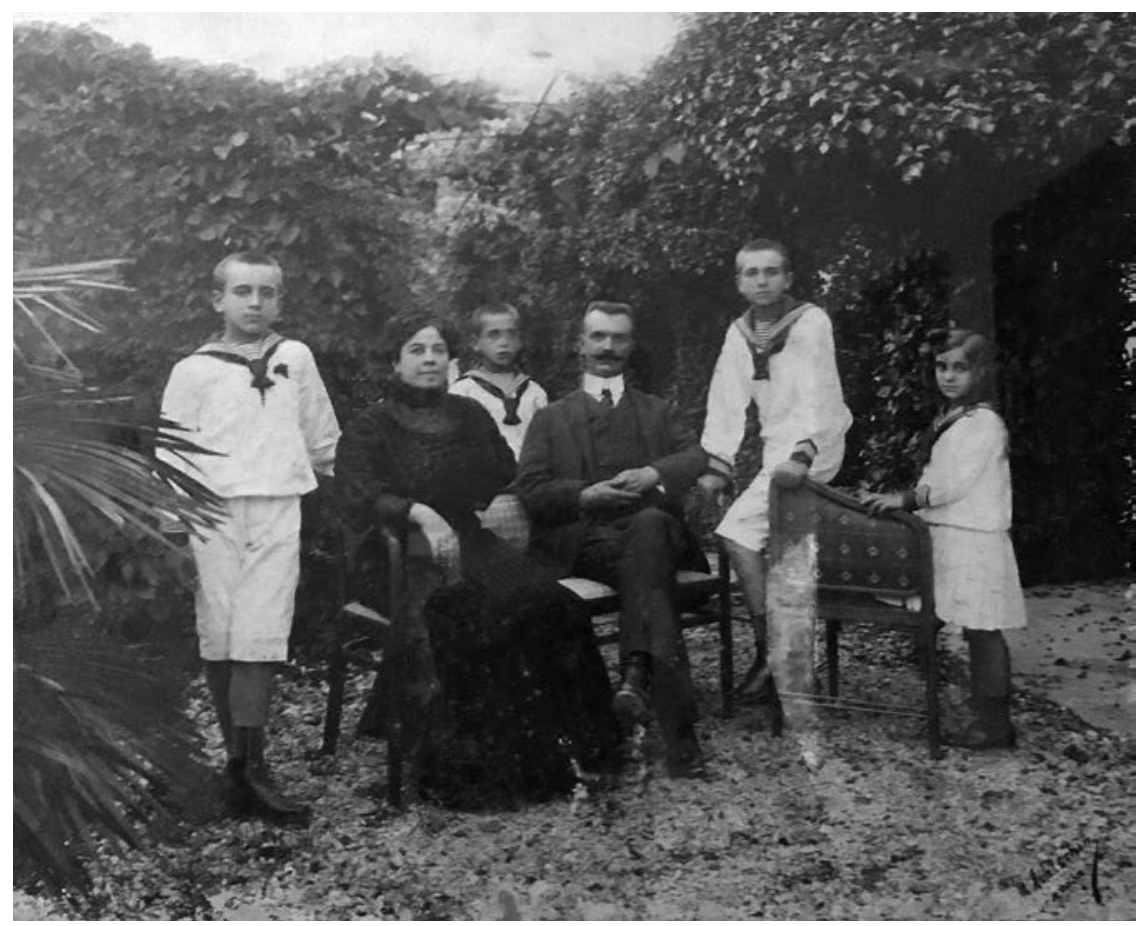

Slika I. Obitelj dr. Balde Bibice (sjedi sa suprugom Đinom rođ. Cviličević, a stoje sinovi Vinko, Ante i Ivo te kći Nevenka)

(obiteljski arhiv, fotografiju ustupila Nevenka Golubović)

u ad hoc povjerenstvo za donju (južnu) Dalmaciju koja je tada uključivala i Boku kotorsku, radi povećanja broja članova. ${ }^{37}$ Odazvao se pozivu člana ministarskoga savjeta dr. Filipa Smolčića (I872. - I954.) i 4. svibnja I9I9. sudjelovao na sastanku dalmatinskih liječnika u Dubrovniku, prvom nakon svršetka rata, na kojem se raspravljalo o "Nacrtu zakona o čuvanju narodnog zdravlja“. 38,39

Društveni ugled koji je uživao potvrđen je i njegovim izborom početkom I920., u Nadzorni odbor Pomorske banke d.d. Gruž. ${ }^{40}$ Bio je omiljen liječnik koji se nesebično zalagao za svoje bolesnike. Kao i prije, sudjelovao je novčanim prilozima u humanitarnim akcijama npr. prilogom od soo dinara za Domus Christi u Dubrovniku u počast preminulog kolege dr. Frana Trošića. ${ }^{41}$

37 Anonim (1914). Iz "Slobodne organizacije liječnika Kralj. Dalmacije". Liječ vjesn /Stal glasn/ 36:96-102.

Anonim (1919). Sastanak liječnika u Dubrovniku. Liječ vjesn 41:234-5.

Marinović, I. (2006), 82-9.

Anonim (1920). Nova uprava. Rad br. 18, 20. 3. 1920, 5.

Anonim (1922). Milodari. Narodna Svijest br. 50, 19. 12. 1922, 3. 
Obitelj dr. Bibice imala je razlog za posebno veseo Božić 1923. godine. Njegov sin Ante, slijedeći očev primjer u izboru zanimanja, promaknut je u Zagrebu na čast doktora sveukupne medicine 22. prosinca 1923. I unuk dr. Balde, sin kćeri Nevenke, Čedomir Golubović (1937. - 2004.) slijedio je primjer djeda i ujaka. Završio je medicinu i radio u ordinaciji opće medicine u Župi Dubrovačkoj. ${ }^{42}$ I Baldov praunuk, sin Čedomirov, Marko Golubović (rg8o.) liječnik je u Općoj bolnici Dubrovnik te nastavlja u četvrtoj generaciji tradiciju obitelji Bibica u Dubrovniku. ${ }^{43}$

Dr. Bibica dugo je bolovao od reumatizma, a njegova smrt od tuberkuloze pluća 8 . veljače i924., u 58 . godini, zabilježena je u Liječničkom vjesniku. ${ }^{44}$ Prema splitskom dnevniku Novo Doba „dr. Baldo Bibica ostavio za sobom najljepšu uspomenu i kao patriot i kao liječnik koji je svoje zvanje shvaćao obavljanjem jedne humane dužnosti“" 45 Posljednji ispraćaj, u nedjelju 9. veljače 1924., vodio je gruški župnik don Niko Zlovečera. Pred brojnim okupljenim sugrađanima, među kojima je bilo i mnogo pacijenata dr. Balda i članova njihovih obitelji, od pokojnika se oprostio njegov kolega i prezimenjak dr. Marko Bibica st. (1878. - 1943.). Obitelj se javno zahvalila svima koji su ga došli pozdraviti. ${ }^{46} \mathrm{O}$ njegovoj omiljenosti svjedoči i nadgrobni spomenik na groblju sv. Mihajla u Lapadu podignut prilozima građana u znak zahvalnosti za liječenje sirotinje u Gružu i Lapadu (slika 2.).

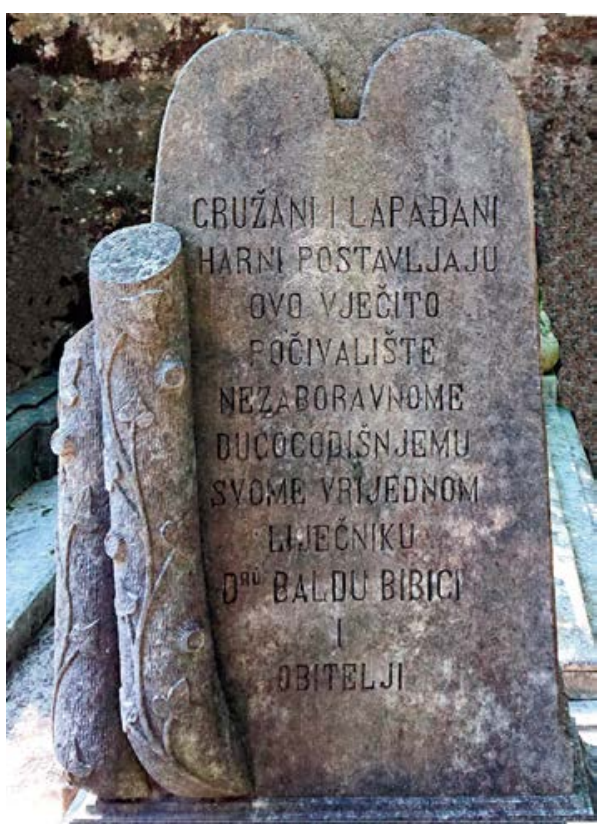

Slika 2. Spomenik na grobu dr. Balde Bibice (fotografija Ana Bakija-Konsuo)

42 Salečić, Milivoj (2004). Zdravstveni djelatnici podrijetlom iz župe dubrovačke koji rade izvan župe. u Salečić Milivoj. Zdravstvene prilike u župi dubrovačkoj i u Dubrovniku tijekom stoljeća. U povodu 110 godina kontinuirane zdravstvene službe u Župi dubrovačkoj (1893.-2003.) Hrvatski liječnički zbor, Podružnica Dubrovnik, Dubrovnik, 196-8.

43 Usmeni podaci dobiveni od dr. Marka Golubovića.

44 Anonim (1924). Umro. Liječ vjesn/Prilog-Staleške vijesti/46:59.

45 Anonim (1924). Dr. Baldo Bibica. Novo Doba br. 34, 10. 2. 1924, 4.

46 Anonim (1924). Zahvala. Dubrovački list br. 4, 23. 2. 1924, 3. 


\section{Ante Bibica}

(Vela Luka, 3I. 3. I897. - Dubrovnik, 5. 7. 1973.)

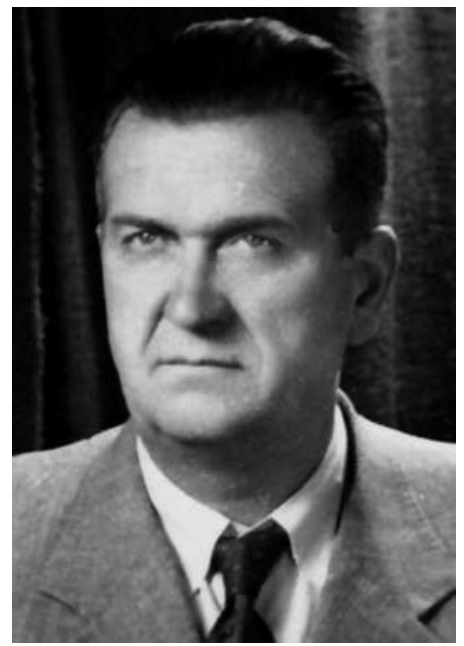

Slika 3. Dr. Ante Bibica (obiteljski arhiv, fotografiju ustupila Nevenka Golubović)

Ante Bibica rođen je 3I. ožujka I897. u Veloj Luci (slika 3.). Ime je dobio po djedu. Od 1903. živio je u Dubrovniku. Tamo je završio pučku školu i gimnaziju. U ratnoj su I9I4./I915. godini za učenike pozvane „pod barjak“ prije svršetka školske godine bili organizirani ispiti zrelosti u izvanrednim rokovima. Osamnaestogodišnji Ante Bibica, unovačen 22. svibnja 1915., pripušten je ispitu zrelosti već 24 . svibnja 1915. i ocijenjen s ocjenom „zrio“. 47 U austrougarskoj vojsci ostao je gotovo tri i pol godine, do 3. studenoga I9ı8. U „Božićnoj akciji“ I915. organizirano je prikupljanje novca za darove „našoj 37. domobranskoj pukovniji“. U Dubrovniku (gradu) prikupljena je ukupno 3ror kruna, u Gružu ukupno 40I,6 kruna, a obitelj dr. Balde Bibice darovala je ıo kruna. ${ }^{48}$

U zimskom semestru I917./19I8. godine upisao je Ante Bibica, na temelju svjedodžbe o ispitu zrelosti u državnoj gimnaziji u Dubrovniku, prvi semestar na Medicinskom fakultetu u Grazu (testirao ga je 29. ožujka I9ı8.). Bio je prijavljen na adresi Hotel Zur goldenen Birne. Na njegov je izbor studija svakako utjecalo sve ono što je mogao od najranije djetinjstva pratiti u životu svoga oca, općinskog liječnika, a moglo je utjecati i ono čemu je svjedočio pune dvije godine sudjelovanja u ratu. Odabrao je Graz premda su se upravo te nastavne godine upisali prvi redovni studenti u prvi semestar novootvorenoga Medicinskog fakulteta u Zagrebu. ${ }^{49}$

Odslušavši dva semestra nastave u Grazu, preselio je ujesen i9ı8. u Zagreb i u školskoj godini ı9ı8./ı9ı9. upisao treći semestar na Medicinskom fakultetu. Medicinar Bibica nazočio je 27. rujna I9I8. redovitoj mesečnoj skupštini

47 Program c. kr. Realne gimnazije u Dubrovniku za školsku godinu 1914/1915, Dubrovnik 1915, str. 25-6.

48 Anonim (1915). Božićna akcija godine 1915. Prava Crvena Hrvatska br. 557/Prilog/, 24. 12. $1915,1-2$.

49 Fatović-Ferenčić, S. (2017), Borba za osnutak Medicinskog fakulteta Sveučilišta u Zagrebu, u: Pećina, M., Klarica, M. (ur.) Medicinski fakultet 1917 - 2017. Zagreb, str.17-31. 
Zbora liječnika u operacijskoj dvorani Bolnice Crvenoga križa u Zagrebu. ${ }^{50}$ No i nakon preseljenja u Zagreb odlazio je u Beč. Doputovao je iz Zagreba i prijavio se kao student u Pansionu America, Kindergasse br. I, kat III., vrata 7 , okrug IX. u Beču od 25. do 31. ožujka 1921. godine. Tada je položio prvi rigoroz jer dva tjedna poslije, pri prijavi I3. travnja 1921. u Ulici Alserstrasse 7, mezanin 3, okrug III., u Beču, uz ime je naveo cand. med. Na toj je adresi ostao do 7. studenoga 1921. i prigodom odjavljivanja naveo, kao buduću adresu u Beču, Inselstädterstr. br. 32, okrug VIII.

Nakon odslušanih deset semestara i položenih ispita promaknut je u doktora medicine u Zagrebu 22. prosinca 1923. godine. ${ }^{7}$ Promociju su vodili rektor prof. dr. Stjepan Zimmermann (1884. - 1963.), prodekan MEF-a prof. dr. Emil Prašek (I884. - 1934.), a promotor je bio prof. dr. Miroslav Čačković (I865. 1930.). Skupa s Bibicom toga su dana na čast doktora medicine u Zagrebu promaknuti Andrija Kesler i Janko Pajas. ${ }^{51}$ Ante Bibica prvi je Dubrovčanin promaknut na Medicinskom fakultetu u Zagrebu, nepunih deset mjeseci nakon što je, 28. veljače 1923., promaknut Zlatan Sremec (1898. - 197I.), prvi student koji je sva tri stroga ispita položio na Medicinskom fakultetu u Zagrebu. ${ }^{52}$

Ante Bibica ostao je u Zagrebu i u Zakladnoj bolnici milosrdne braće (tada još na Jelačićevu placu) proveo liječnički staž, od i6. siječnja i924. do I6. siječnja I925. godine. Po završenom stažu vratio se u rodni kraj. Liječničku karijeru započeo je kao privatni liječnik opće prakse u Gružu (od 20. siječnja do 30. rujna 1925.) i u općini Ston (od I. listopada 1925. do I. listopada 1926.). Godine 1925. izabran je u upravu Gruškoga omladinskoga športskoga kluba (GOŠK).

Specijalizaciju na Sveučilišnoj klinici za kožne i spolne bolesti u Beču Ante Bibica je započeo 4. studenoga I926. godine. Bilo je to neposredno nakon što je dotadašnji predstojnik prof. dr. Gustav Riehl umirovljen, a prof. dr. Leopold Arzt (1883. - 1955.) održao 26. listopada 1926. nastupno predavanje Ferdinand v. Hebra i dermatologija našeg doba.$^{53}$ Dr. Bibica je u Beču ostao do 4. studenoga 1928. jer mu je specijalizacija trajala dvije godine, a troškove je snosio sam. Ministarstvo narodnog zdravlja u Beogradu odobrilo mu je 30 . studenoga I928. naslov specijalista.

\footnotetext{
50 Anonim (1918). Redovita mjesečna skupština. Liječ vjesn 40:317.

51 Vučak, Ivica (2017). Janko Pajas - autor prvog priručnika za studente medicine na Medicinskom fakultetu u Zagrebu. mef.hr 2,54-6.

52 Vučak, I. (2005) Tri istaknuta liječnika u Hrvatskoj seljačkoj stranci (II) (Zlatan Sremec) Liječ nov br. 44, str. 54-5.

53 Anonim (1926). Notizen. Wien med wochenschr 76:1288.
} 
Nakon završetka specijalizacije I4. studenoga 1928. vratio se kući. Povratkom u Dubrovnik zateklo ga je ukidanje veneričnoga odjela u bolnici utemeljenoga prije svega šest godina. Naime, u dubrovačkoj su bolnici 1922. bile uvedene specijalističke službe organiziranjem tri odjela - kirurškog, internističkog i veneričnog 5 . . Ponovno je, ali samo dva mjeseca (od 9. studenoga I928. do 9. siječnja 1929.) radio u Gružu kao privatni liječnik, a zatim je kao specijalist za dermatovenerologiju preuzeo Io. siječnja I929. kožno-venerični dispanzer u Dubrovniku. Njega je utemeljio i od I922. vodio Lujo Fouque (I887. - I980.), prvi školovani specijalist dermatovenerologije ne samo u Dubrovniku već i u široj okolici, uključujući dio Hercegovine i Crne Gore., ${ }^{5,6}$ Bibica je u Dubrovniku vo-

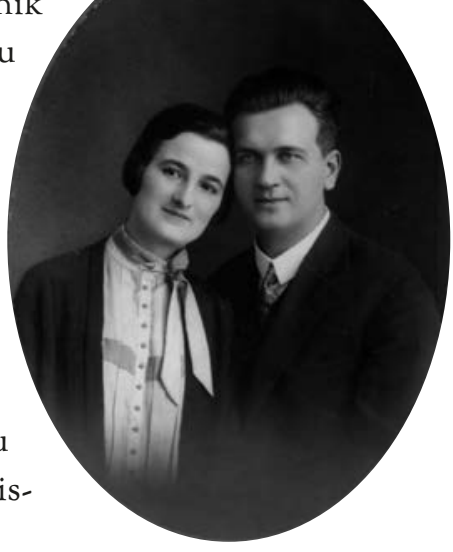

Slika 4. Dr. Ante Bibica sa suprugom Katicom rođ. Gabrić (obiteljski arhiv, fotografiju ustupila Nevenka Golubović) dio i privatnu ambulantu za kožne i spolne bolesti (slika 4.).

Bio je član Liječničkog udruženja dubrovačke oblasti sa sjedištem u Dubrovniku, utemeljenoga I923., kojemu je, ukinućem oblasnih samouprava i osnutkom banovina, ime promijenjeno u Dubrovačko liječničko udruženje (Duliud). U radnoj godini I93I. - I932. održao je predavanje zanimljiva naslova Imunitet $i$ alergija luesa. ${ }^{54}$ Sudjelovao je I3. travnja i935. na zajedničkoj drugarskoj večeri članova Duliuda održanoj nakon društvenih predavanja. ${ }^{55} \mathrm{Na}$ prvoj sjednici Duliuda u razdoblju 1936. - I37. dr. Ante Bibica držao je predavanja o homoseksualnoj prostituciji. ${ }^{56}$ Sudjelovao je i na pučko-prosvjetnim predavanjima. U novinama je zabilježeno njegovo predavanje o ženskoj prostituciji i spolnim bolestima 6. travnja 1937. u prostorijama Narodne ženske zadruge u Dubrovniku. ${ }^{57}$ Osim njega, predavači u režiji mjesnog Hrvatskog akademskog kluba bili su dr. Mirko Mladinov (I893. - I970.) (Muška prostitucija) i dr. Vlaho Poljanić (I867. - I949.) (Nauka o nasljeđivanju). Na redovitoj

54 Anonim (1932). Iz "Duliud"-a. Liječ vjesn /Stal glasn/54:318.

55 Anonim (1935). Zajednička drugarska večera "Dubrovačkog liječničkog udruženja" ("Duliuda“). Liječ vjesn 57:457-8.

56 Anonim (1937). Rad "Dubrovačkog liječničkog udruženja” u 1936. - 37. godini. Liječ vjesn $59: 425$.

57 Anonim (1937). Posljednji broj usmenih novina Hrvat Akad. Kluba. Jadran dnevn br. 82, 8. 4. 1937, 4 . 
glavnoj godišnjoj skupštini Duliuda 8. listopada 1938. u prostorijama novoadaptiranog Hotela Pošta u Pilama funkcija blagajnika novoizabranoga Upravnog odbora povjerena je dr. Anti Bibici. ${ }^{58}$

Bio je učlanjen u Orjen, podružnicu Hrvatskog planinarskog društva (HPD) u Dubrovniku. Uza zapis o radu podružnice HPD-a objavljena je u časopisu Hrvatski planinar fotografija ,agilnih članova pred kraj 193I.“, na kojoj je i dr. Ante Bibica. ${ }^{59} \mathrm{Na}$ glavnoj godišnjoj skupštini 8. ožujka 1933. izabran je za potpredsjednika Podružnice. ${ }^{60}$ Predsjednik je bio dr. Đuro Orlić (I886. I98I.), a u odboru dr. Katica Šupe (1897. - 1967.).

Bio je i jedan od utemeljitelja i odbornik u prvoj upravi šahovskoga kluba utemeljenoga 20. listopada I933. pod nazivom Šah-klub. ${ }^{61}$ Predsjednik je bio dr. Filip Smolčić. Sastajali su se u prostorijama kavane Dubravka na Pilama. No već 1935. dr. Ante Bibica nije bio među članovima uprave šahovskog kluba.

Održao je više predavanja kao član Rotary cluba (RC) Dubrovnik utemeljenog 2. prosinca 1933. godine. U prosincu 1936. u Hotelu Imperial u Dubrovniku predavao je "sa sanitetskoga gledišta" o muškoj prostituciji u Dubrovniku „zbog koje posebno stradaju mladi ljudi“, a o istoj je pojavi "sa socijalnog gledišta“ govorio Matija Vidoević, u godini 1938./1939. predsjednik RC Dubrovnik. . $5,62^{2}$

Među novim članovima Hrvatskoga liječničkog zbora u Zagrebu koji su pristupili sredinom 194I. bio je i dr. Ante Bibica, liječnik venerične ambulante Doma narodnog zdravlja u Dubrovniku. ${ }^{63}$ U ljeto ratne 1942. dr. Ante Bibica, ,zdravstveni viši pristav VIII. činovnog razreda, 2. stupnja“ promaknut je „za zdravstvenog nadzornika VII. čin. razreda kod Doma narodnog zdravlja u Dubrovniku."64

Aktivni dugogodišnji član Jedriličarskog kluba Orsan, dr. Ante Bibica imao je stalno mjesto za svoju barku u prekrasnoj lučici Orsan, smještenoj u

\footnotetext{
Anonim (1938). "Duliud”-ova glavna godišnja skupština. Liječ vjesn 1938;60:645.

Orlić, Đuro (1938). Društvena kronika (1928-1938). Hrvatski planinar 41, 338-42.

60 Petković, Milivoj (1993). Hrvatsko planinarsko društvo „Orjen”, u: Petković M. Tjelesno vježbanje i šport u Dubrovniku od 14. stoljeća do 1941. godine. Matica Hrvatska Dubrovnik i Dubrovački športski savez, Dubrovnik, 168-175.

61 Povijest Šahovskog kluba „Dubrovnik”. Dostupno na: http://www.skdubrovnik.hr/php/povijest.php?clanak_id=11 (pristupljeno 21. prosinca 2018.).

62 Anonim (2009). Rad u skladu s najljepšom tradicijom Grada. Povijest rotarijanstva 1928. 1941. rotary magazin 4(8/9):40 - 3. Dostupno na: https://issuu.com/rotary_magazin/docs/rotary-magazin-br.-08-09 (pristupljeno 28. prosinca 2018.).

63 Anonim (1941). Novi članovi pristupili u Hrvatski liječnički Zbor. Liječ vjesn 63:414.

64 Anonim (1942). Razne vijesti Liječ vjesn 64:261.
} 
uvali Gruž, po kojoj je klub dobio ime. Velika ljubav bili su mu more i podvodni ribolov. ${ }^{65}$

Tijekom i nakon Drugoga svjetskog rata ostao je u državnoj službi u Domu narodnog zdravlja u Dubrovniku kao šef Kožno-veneričnog dispanzera. Honorarno je jedan sat dnevno radio za zaposlenike željeznice, a imao je i privatnu praksu u vlastitoj ordinaciji. Ponovno je pristupio Zboru liječnika Hrvatske. ${ }^{66}$ U Dubrovniku je 1947. utemeljena podružnica Zbora liječnika Hrvatske za Dubrovnik na čelu s predsjednikom dr. Kristom Regjom (1892. - 1964.), a Ante Bibica je bio tajnik do 1949. godine. ${ }^{67}$ Održao je niz predavanja u Dubrovniku i selima u okolici o važnosti sprječavanja, ranog prepoznavanja i ispravnog liječenja kožnih i spolnih bolesti. Bio je član zdravstvene ekipe kotarskog odbora Crvenoga križa u Dubrovniku i zajedno s liječnicima specijalistima dr. Katicom Carić, dr. Đurom Orlićem, dr. Ivom Bobićem (r896. - 1973.) te zubarom N. Savinovićem i šestero aktivista posjetio selo Ljutu u Konavlima. ${ }^{68}$ Sudjelovao je na kongresima dermatologa u Beogradu i Beču. Umirovljen je rg6r., a zbog potrebe službe nastavio je raditi do 1967. godine. Zanimanje za novosti u struci zadržao je do kraja života.

Umro je 5. srpnja 1973. u 76. godini. Pokopan je na groblju svetog Mihajla pokraj svojih roditelja. U oproštajnom govoru Bogomil Cezarović ${ }^{6}$, specijalist dermatovenerologije i njegov nasljednik, istaknuo je ljudske i liječničke vrline po kojima će Bibica ostati zapamćen. Supruga Katica je u prigodnoj novinskoj obavijesti zahvalila "svima, a posebno liječničkom kolegiju i medicinskom osoblju bolnice Dubrovnik".70

\section{ZAKLJUČAK}

Životi dr. Balda i dr. Ante Bibice još su jedan primjer u kojem je u izboru studija sin slijedio oca liječnika unatoč poznavanju, iz najveće blizine, i manje ugodnih strana te profesije. Oni su potvrda doživljaja liječništva ne samo kao zanimanja nego kao životnog poziva, a taj se doživljaj prenosi i širi

65 Usmeni navod g. Marka Prosenice, današnjeg direktora kluba Orsan, koji i danas u svome domu čuva pušku za podvodni ribolov koju mu je darovao doktor Ante Bibica.

66 Anonim (1948). Novi članovi. Liječ vjesn 70:293.

67 Hrvatski Liječnički Zbor - podružnica Dubrovnik. Dostupno na http://hlz.mef.hr/ Dubrovnik.htlm). (pristupljeno 28. prosinca 2018.).

68 Anonim (1950). Kotarski odbor Crvenoga križa u Dubrovniku. Jugoslavenski Crveni Križ 1, siječanj-veljača 1950, 7.

69 Bogomil Cezarović (Dubrovnik, 1931.) diplomirao je na Medicinskom fakultetu Sveučilišta u Zagrebu 1958./1959.; vodio je Odjel za kožne i spolne bolesti od njegova osnutka 1970. do svoga umirovljenja 2000.

70 Anonim (1973). Javna zahvala. Dubrovački vjesn br. 1187, 13. 7. 1973, 9. 
primjerom i usvaja nesvjesno. Pokušali smo faktografske činjenice iz života dvojice dubrovačkih liječnika s kraja I9. i prve polovice 20. stoljeća promatrati s obzirom na razdoblje u kojemu su živjeli i radili. Bili su aktivni ne samo u strukovnim udruženjima nego i u javnom, društvenom i sportskom životu tadašnjeg Dubrovnika. Analizom njihova doprinosa stekli smo uvid u stručni rad liječnika toga doba, ali i u bogat javni i društveni život Dubrovnika, kojemu su liječnici poput Balda i Ante Bibica često bili inicijatori i aktivni sudionici. Upoznavanje njihova djelovanja važno je u kontekstu povijesti medicine u Dubrovniku jer se iz njega može iščitati društveni život grada toga doba. Rekonstrukcija njihova života i rada prinos je i hrvatskoj medicinskoj historiografiji.

\section{IZVORI I LITERATURA}

1. Anonim (1866). Esami di maturità. Narod br. 60, 3. 8. 1866, 3.

2. Anonim (1886). HAD“Zvonimir“. Glas Hercegovca br. 46, 13. 11. 1886, 4.

3. Anonim (1887). Članovi "Bratovščine hrvatskih ljudi u Istri“. Naša Sloga br. 44, 3. $11.1887,3$.

4. Anonim (1887). Hrv. akad. Društvo „Zvonimir“ u Beču. Narodni List br. 87, 5. 11. 1887, 3.

5. Anonim (1889). Godišnja skupština HAD “Zvonimir”-a. Narodni List br. 88, 6. 11. 1889,3 .

6. Anonim (1889). Iz Hrvatskog pripomoćnog društva u Beču. Obzor br. 255, 5. 11. $1889,3$.

7. Anonim (1893). Dr. Baldo Bibica. Narodni list br. 84, 21. 10. 1893, 3.

8. Anonim (1893). Iz Uredništva. Crvena Hrvatska br. 29, 22. 7. 1893, 4.

9. Anonim (1893). Pet naših doktura u dva dana. Naša Sloga br. 12, 23. 3. 1893, 2.

10. Anonim (1893). Prve krune. Crvena Hrvatska br. 23, 10. 6. 1893, 3.

11. Anonim (1893). Prve krune. Crvena Hrvatska br. 24, 17. 6. 1893, 3.

12. Anonim (1893). Transfer. Das Österreichische Sanitätswessen br. 44, 2. 11. 1893, 520.

13. Anonim (1894). Dr. Baldo Bibica. Crvena Hrvatska br. 30, 28. 7. 1894, 4.

14. Anonim (1894). "Družtvo sv. Ćirila i Metoda u Istri”. Crvena Hrvatska br. 32, 11. 8. 1894, 3.

15. Anonim (1894). Premještaj. Narodni list br. 5, 17. 1. 1894, 3.

16. Anonim (1894). Promocija. Crvena Hrvatska br. 13, 1. 4. 1894, 3.

17. Anonim (1895). Godišnja skupština. Starohrvatska prosvjeta 1:260-1. 
18. Anonim (1896). Imenik redovitih članova Hrvatskog starinarskog društva 1896. godine. Starohrvatska prosvjeta 2:268.

19. Anonim (1899). "Družba sv. Ćirila i Metoda u Istri”. Narodni list br. 19, 8. $3.1899,3$.

20. Anonim (1899). Iznenadna smrt. Osvit br. 17, 25. 2. 1899, 5.

21. Anonim (1899). Novi članovi. Liječnički vjesnik 21:312.

22. Anonim (1899). Proslava 25. godišnjice obstanka sbora liečnika kraljevina Hrvatske i Slavonije u Zagrebu. Prinos od 2 for. uplatili su do 5. prosinca 1899. Liječnički vjesnik 1899;21:451.

23. Anonim (1906). Iskaz p.n. gg. članova koji svoj prinos sboru duguju uključivo godinu 1906. Liječnički vjesnik ;28/11-prilog/:1.

24. Anonim (1914). Iz "Slobodne organizacije liječnika Kralj. Dalmacije". Liječnički vjesnik 36:100.

25. Anonim (1915). Božićna akcija godine 1915. Prava Crvena Hrvatska br. 586 / Prilog/, Božić 1915, 24. 12. 1915, 1-4.

26. Anonim (1918). Redovita mjesečna skupština. Liječnički vjesnik 40:317.

27. Anonim (1919). Sastanak liječnika u Dubrovniku. Liječnički vjesnik 41:235.

28. Anonim (1920). Nova uprava. Rad br. 18, 20. 3. 1920, 5.

29. Anonim (1922). Milodari. Narodna Svijest br. 50, 19. 12. 1922, 3.

30. Anonim (1924). Dr. Baldo Bibica. Novo Doba br. 34, 10. 2. 1924, 4.

31. Anonim (1924). Umro. Liječnički vjesnik 46:59.

32. Anonim (1924). Zahvala. Dubrovački list br. 4, 23. 2. 1924, 3.

33. Anonim (1926). Notizen. Wiener medizinische Wochenschrift 76:1288.

34. Anonim (1932). Iz "Duliud"-a. Liječnički vjesnik/Staleški glasnik/54:318.

35. Anonim (1935). Zajednička drugarska večera "Dubrovačkog liječničkog udruženja“ ("Duliuda"). Liječnički vjesnik /Staleške vijesti/57:457-8.

36. Anonim (1937). Posljednji broj usmenih novina Hrvat Akad. Kluba. Jadranski dnevnik br. 82, 8. 4. 1937, 4.

37. Anonim (1937). Rad Dubrovačkog liječničkog udruženja u 1936. - 37. godini. Liječnički vjesnik /Staleške vijesti/ 59:425.

38. Anonim (1938). "Duliud”-ova glavna godišnja skupština. Liječnički vjesnik 60:645.

39. Anonim (1941). Novi članovi pristupili u Hrvatski liječnički Zbor. Liječnički vjesnik 63:414.

40. Anonim (1942). Razne vijesti. Liječ vjesn 64:261.

41. Anonim (1948). Novi članovi. Liječnički vjesnik 70:293. 
42. Anonim (1950). Kotarski odbor Crvenoga križa u Dubrovniku. Jugoslavenski Crveni Križ 1, siječanj-veljača 1950, 7.

43. Anonim (1973). Javna zahvala. Dubrovački vjesnik br. 1187, 13.7.1973, 9.

44. Anonim (2009). Rad u skladu s najljepšom tradicijom Grada. Povijest rotarijanstva 1928. - 1941. rotary magazin 4 (3/4):40-3. Dostupno na: https://issuu. com/rotary_magazin/docs/rotary-magazin-br.-08-09 (pristupljeno: 28 prosinca 2018.).

45. Bakija-Konsuo, Ana (2011). Obilježavanje 40 godina rada Službe za kožne i spolne bolesti u Dubrovniku. Dubrovački horizonti, 48, 40-50.

46. Bakija-Konsuo, Ana and Marlais, Matko (2012). A brief history of Dermatovenereology in Dubrovnik. Acta Dermatovenerol Croat, 20, 141-7.

47. Bakija-Konsuo, Ana i Vučak, Ivica (2017) Dr. Ante Bibica (1897-1973) - prvi Dubrovčanin s diplomom zagrebačkog Medicinskog fakulteta, Liječ nov br. 158, 92-3.

48. Diklić, Marjan (1998) Pravaštvo u Dalmaciji do kraja prvoga svjetskoga rata, Matica hrvatska i Zavod za povijesne znanosti HAZU, Zadar, 198, 263, 279.

49. Fatović-Ferenčić, Stella (2017) Borba za osnutak Medicinskog fakulteta Sveučilišta u Zagrebu. u Pećina M, Klarica M. (ur.) Medicinski fakultet 1917 2017. Zagreb, Sveučilište u Zagrebu, Medicinski fakultet, 17-31.

50. Hajdarhodžić, Hamdija, Arneri, Rafo, Maroević, Hrvoje, Nemec, Marija (1963). Korespodencija Frana Supila iz perioda 1891. - 1914. Arhivski vjesnik 6, 40. Dostupno na: https://library.hungaricana.hu/hu/view/CroatianStateArchives. AV_III_06_1963/?pg = 43\& layout = s\&query = bibica\%20baldo (pristupljeno 21 . srpnja 2019.).

51. Hrvatski Liječnički Zbor - podružnica Dubrovnik. Dostupno na http://hlz.mef. hr/Dubrovnik.htlm) (pristupljeno 28. prosinca 2018.).

52. Marinović, Ivo (2006). Liječnici dubrovačke bolnice; od 1840. do 1940. Zagreb, Medicinska naklada, Zagreb, 45-59, 82-9.

53. Orlić, Đuro (1938). Društvena kronika (1928-1938). Hrvatski planinar 41, 341.

54. Peričić, Božo (1899). O razprostranjenju nekih bolesti po Dalmaciji, Liječnički vjesnik, 21, 428.

55. Peričić, Božo (1933). Kao mlad ljekar u šibenskoj bolnici. u Machiedo Jerko, Lalić Jozo, Škarica Miloš (ur.) Spomen-knjiga o pedesetgodišnjici banovinske bolnice u Šibeniku, 1883-1933, Šibenik, 53-7.

56. Petković, Milivoj (1993). Hrvatsko planinarsko društvo „Orjen”, u: Petković, Milivoj. Tjelesno vježbanje i šport u Dubrovniku od 14. stoljeća do 1941. godine. Matica Hrvatska Dubrovnik i Dubrovački športski savez, Dubrovnik, 168-75.

57. Povijest Šahovskog kluba „Dubrovnik”. Dostupno na: http://www.skdubrovnik.hr/php/povijest.php?clanak_id=11 (pristupljeno: 21. prosinca 2018. 
58. Program ć. kr. Realne gimnazije u Dubrovniku za školsku godinu 1914./1915., Dubrovnik 1915, 19, 25-26.

59. Salečić, Milivoj (2004), Zdravstveni djelatnici podrijetlom iz župe dubrovačke koji rade izvan župe, u: Salečić, Milivoj ur., Zdravstvene prilike u župi dubrovačkoj i u Dubrovniku tijekom stoljeća. U povodu 110 godina kontinuirane zdravstvene službe u Župi dubrovačkoj (1893. - 2003.) Hrvatski liječnički zbor, Podružnica Dubrovnik, Dubrovnik, str. 196-8.

60. Vučak, Ivica (2004). Nikola Marinković - prvi predsjednik Liječničke komore u Dalmaciji - uz stotu obljetnicu njezina osnutka. Liječničke novine br. 32, 53-5.

61. Vučak, Ivica (2005). Tri istaknuta liječnika u Hrvatskoj seljačkoj stranci (II) (Zlatan Sremec). Liječničke novine br. 44, str. 54-5.

62. Vučak, Ivica (2015). Liječnička komora u Dalmaciji od 1903. do 1946. u Hrvatska liječnička komora 2005. - 2015. (ur. Ž. Poljak, I. Vučak), HLK, Zagreb, 2015, str. 34-54.

63. Vučak, Ivica (2017). Janko Pajas - autor prvog priručnika za studente medicine na Medicinskom fakultetu u Zagrebu. mef.hr 2:54-6.

64. Vučak, Ivica (2019) Zaklada za osnutak Medicinskog fakulteta u Zagrebu. Liječničke novine br. 183, 71-3.

\section{SUMMARY}

Medicine and physicians in Dubrovnik during the last two centuries, i.e. in the period after the dissolution of the Republic of Dubrounik by Napoleon's Army, have attracted less interest among medical historians. In this paper, the lives and medical careers of two physicians from Dubrovnik, father and son, Baldo and Ante Bibica, have been reconstructed from the end of the nineteenth and the first half of the twentieth century by searching through the contemporary medical journals and newspapers as well as private archives of the members of family Bibica. Baldo Bibica graduated medicine in Vienna and spent the whole professional life as a municipal physician, at first, in the places in the vicinity of Dubrovnik and from 1903 in Gruž. Ante Bibica studied medicine in Graz and in Zagreb to become the first person from Dubrovnik promoted at the School of Medicine, Zagreb University. He specialized in dermatovenereology in Vienna and worked, as a specialist, in Dubrovnik. They both were active in the professional medical societies (at local and national levels) and were influential in the social life in Dubrownik.

Keywords: medicine, history of medicine, Dubrownik, Dalmatia, Croatia 